\title{
A ley-farming system for marginal lands based upon a self-regenerating perennial pasture legume
}

\author{
Tom Edwards ${ }^{1,2} \cdot$ John Howieson ${ }^{2} \cdot$ Brad Nutt $^{2} \cdot$ Ron Yates $^{1,2} \cdot$ Graham O'Hara $^{2} \cdot$ Ben-Erik Van Wyk ${ }^{3}$ \\ Accepted: 18 January 2019 / Published online: 11 February 2019 \\ (C) INRA and Springer-Verlag France SAS, part of Springer Nature 2019
}

\begin{abstract}
Annual-based farming systems represent some of the most highly disturbed terrestrial ecosystems on the planet. They are also highly exposed to climate variability. Many wheatbelt systems of southern Australia rotate annual crops with annual pastures, where the productivity of both is reliant upon seasonal rainfall. Perennial plants, in contrast, are less reliant upon both consistent rainfall and annual establishment, so one approach to decrease exposure to climate variability and disturbance in agriculture is to increase the proportion of the farm sown to perennial species. Perennial pasture or forage species offer immediate possibilities for transformation of agricultural ecosystems as they offer high protein feed to animals, often when green feed is most limiting, and concomitantly restore soil fertility. However, there are no perennial forage legumes adapted to acid and infertile soils in lowrainfall regions of the developed world, either in temperate or Mediterranean climates. Here, we review the recent research efforts to domesticate a perennial legume for these regions. Reasons for the lack of success are provided by a comparison of the attributes of the legumes evaluated in recent research programs and the limitations of these legumes as assessed by reviews and publications. This manuscript outlines an alternative approach to domestication of perennial forage legumes for acid soils and introduces new concepts in ley farming in an Australian context that might support the development of more sustainable agro-ecosystems. It highlights situations where very hard-seeded annual legumes have been successfully included in modern intensive cropping systems, and where perennial legumes may underpin ley-farming systems on infertile soils that normally produce low crop yields. Both innovations require the legume and their nodule bacteria to be sown only once in decades and address concerns about the sustainability of modern agro-ecosystems.
\end{abstract}

Keywords Self-regenerating legumes $\cdot$ Perennial $\cdot$ Rhizobia $\cdot$ Ley farming $\cdot$ Agro-ecosystems $\cdot$ Lebeckia ambigua

\section{Contents}

1. Introduction

2. Ley farming

2.1 The development of ley farming in Australia based on the agro-ecosystems of Europe

2.1.1 The crucial role of nodule bacteria in ley-farming

2.1.2 How "hard seed banks" are used in ley-farming systems

2.2 The inherent weakness of ley farming with annual species
2.2.1 The hydrological imbalance caused by annualbased farming systems

2.2.2 The FEED-GAP in annual ley-farming systems

2.2.3 Susceptibility to false breaks

3. Developing an ecological approach to select suitable perennial legumes for ley farming

3.1 Tackling the first limitation — selecting plants for marginal lands that are least profitable for cropping

3.2 Tackling the second limitation-from where to source new plant germplasm?
Tom Edwards

tom.edwards@dpird.wa.gov.au

1 Department of Primary Industries and Regional Development Western Australia, South Perth, WA 6156, Australia
2 Centre for Rhizobium Studies, Murdoch University, Murdoch, WA 6150, Australia

3 Department of Botany and Plant Biotechnology, University of Johannesburg, Johannesburg, South Africa 
3.2.1 The Fynbos of RSA and the wheatbelt regions of Western Australia

3.2.2 Grazing pressure in the Kwongan and the Fynbos

3.3 Tackling the third limitation - selecting perennial plants that will complement current farming systems

3.3.1 Understanding disturbance and opportunities for recruitment

4. "Hard seed" produced by perennial legumes and its potential exploitation in perennial ley systems

4.1 Is it possible to develop persistent and hard-seeded perennial legumes to fit within ley-farming systems by utilising hard seed?

4.2 Field softening of the hard seed of Lebeckia ambigua

4.3 Further questions to be answered

5. Conclusion

\section{Introduction}

In a recent review, Crews et al. (2016) stated "Humanity's long-standing dependence on a disturbance-based food and fiber producing ecosystem has resulted in degraded soil structure, unsustainable levels of soil erosion, losses of soil organic matter, low nutrient and water retention, severe weed challenges, and a less-diverse or functional soil microbiome." We concur with those concerns, which the authors considered should be addressed by the development of perennial grain crops. We offer a parallel and more immediate solution. We propose that the development of a ley-farming system (defined below), based upon perennial, self-re-seeding forage legumes for animal production, would greatly reduce ecosystem disturbance by moving from an annual plant-based system that is regularly cropped to a perennial-based system with infrequent crop cycles. We further suggest the target edaphic niche should be the least productive cropping soils in lowrainfall regions. These currently have the lowest profitability in cropping-dominant agro-ecosystems based upon annual plants. This is a pragmatic research target that implements the systems-based approach to post-industrial-era agricultural sustainability proposed by Ikerd (1993).

\section{Ley farming}

Ley-farming systems that are based on self-regenerating annual legumes grown in rotation with annual crops go part of the way to addressing the concerns of Crews et al. (2016). The pasture phase provides inputs of organic matter and has reduced tillage, with less erosion, fertiliser and herbicide applications. The ley-farming systems of southern Australia (including Western Australia-WA) are considered some of the most advanced low-input agro-ecosystems in the world
(Keating and Carberry 2010). These systems are integral to meeting the demands facing modern agriculture because they (as discussed in Section 2.1):

- Are closely modelled on ecological systems

- Are adapted to marginal farmland and subsistence farming operations

- Utilise biological pathways to improve soil nutrition

- Reduce the frequency of tillage

- Improve the biodiversity of farming land

However, these systems also have inherent frailties as a result of being over-reliant on a small suite of adapted annual legume species (discussed in Section 2.2), and it remains a challenge to achieve growth in productivity within these particular agro-ecosystems without rescinding sustainability (Schoknecht 2015). However, we consider these systems an excellent prototype to discuss the deficiencies of modern agriculture in a wider context, whilst also providing a basis from which to seek improvement in sustainability.

\subsection{The development of ley farming in Australia based on the agro-ecosystems of Europe}

The majority of the Western Australian wheatbelt region (WA) is characterised by having relatively poor soil fertility and low (250-500 mm) annual rainfall (Moore 2001). This set of edaphic conditions provided a significant challenge to European settlers attempting to achieve adequate food production through their conventional agricultural practices of the time. Contemporary ley farming now practiced therein is a system which rotates between crop and pasture phases as described by Donald (1965), where the pasture phase is usually a mixed sward comprised of self-regenerating annual plants, including legumes. If managed for legume dominance, this phase can increase soil fertility and impede the buildup of pests and diseases that occur in the crop phase (Angus and Peoples 2012). Animals can also graze the pasture, providing meat and wool whilst simultaneously helping to control weeds by eating them (Loi et al. 2005).

The value of regenerating naturalised legume species was common knowledge in agriculture long before Australian settlement (Henzell 2007). Without a sophisticated knowledge of legumes, Roman scholar Marcus Terentius Varro in 37 BC (approximately) wrote of the benefits of resting the land every second year to allow plants that, when cut and left, will improve the soil (Savio 2011). However, no suitable legumes naturally occurred in the Australian landscape, and it was not until 1889 that South Australian farmer AW Howard recognised the value of annual legume species that had been incidentally transported with sheep from the Mediterranean basin (Henzell 2007). Despite intermittent advances in farming technology and machinery since settlement, crop yields 
did not increase until this adoption of domesticated legumes. This decision arose from an increasing ecological understanding and awareness (Donald 1965; Puckridge and French 1983).

In reviewing ley farming in Australia, Donald (1965) wrote "the use of fertilized, leguminous pastures stands as the greatest factor of favourable environmental change in our agriculture since first settlement". Perhaps as a consequence of this success, the development of well-adapted legumes for similar pasture-based farming systems has become a primary focus of many research programs, throughout the developed and developing world, for over 50 years (Miles 2001).

However, the ley farming referred to by Donald (1965) has evolved in WA in the 50 years since that review, in response to a series of biological, climatic and economic challenges (Howieson et al. 2000). These are, briefly, reduced and less reliable rainfall, increased soil acidity, widespread use of herbicides and intensification of cropping, the latter driven by the greater profitability of grain production enterprises relative to animal-based enterprises (Anwar et al. 2015; Bathgate and Pannell 2002). These challenges have mitigated against the success of the key pasture legumes that inspired the Donald (1965) review-Trifolium subterraneum and Medicago spp. In response to these challenges, a sustained research and development effort over the past 30 years domesticated a number of alternative annual pasture legumes with different physiology, and these are having a remarkable impact, despite intensification of cropping (Howieson et al. 2000; Loi et al. 2005; Nichols et al. 2007). To achieve this, researchers returned to the Mediterranean basin to find and collect species in the regions considered to have the lowest rainfall and most hostile acid infertile soils (Howieson 1995).

Ley farming with this "second generation" of annual legumes in WA has evolved to include crop:pasture sequences of $1: 1 ; 2: 1,3: 1$ and even 4:1 made possible by the development of very hard-seeded, deep-rooted and early maturing cultivars of Ornithopus and Biserrula (Loi et al. 2005; Nutt 2012) which self-regenerate, and resilient rhizobia bacteria which survive in hostile soils in the absence of their host (see Section 2.1.1). Juxtaposed against the traditional ley farming described by Donald (1965), where the pasture phase regenerated from dormant seed and typically lasted for 1-3 years, we now have up to a three-fold decrease in the frequency of the pasture years in rotation (from 2:3 to $4: 1)$. However, the new annual pasture legumes are reliable in these intensively cropped systems (Hackney et al. 2015), and we contend they will continue to ameliorate some of the sustainability concerns raised by Crews et al. (2016). Specifically, those benefits offered to the agroecosytem by sophisticated ley-farming systems are substantial inputs of organic nitrogen (up to 300 units per ha) and organic matter, reduced tillage and reduced herbicide application. We suggest the new legumes be implemented on the soils of better quality, which deliver a consistently high crop seed yield.

\subsubsection{The crucial role of nodule bacteria in ley farming}

A key benefit of legumes in ley farming is in the ability of their nodule bacteria (rhizobia) to assimilate atmospheric nitrogen (N) (Ronner et al. 2016). These bacteria persist in the soil between the crop phases and are able to nodulate their legume host when it is allowed to regenerate (Howieson 1995). Successful nodulation enables the pasture phase to replace nitrogen exported through both cropping (Angus and Peoples 2012) and animal enterprises (Li et al. 2008). The legume-rhizobia symbiosis is a fundamental system for the health and function of global terrestrial ecosystems (Herridge et al. 2008; Crews and Peoples 2004) and is considered by some as second only to photosynthesis as the most important biological process on earth (Lindstrom et al. 2010).

Nodule bacteria that are competent as soil saprophytes in the crop phase when the legumes are absent, but which can nodulate their legume host in the pasture phase to fix N, are thus essential elements of low-input farming practices. Because legumes require specific nodule bacteria which are often absent when legumes are transported to new environments, the selection of appropriate nodule bacteria when domesticating new legumes is a key to successful innovation (Howieson and Ballard 2004). This is an important underlying consideration throughout the remainder of this manuscript.

\subsubsection{How "hard seed banks" are used in ley-farming systems}

An impermeable seed coat is often referred to as "hard" seed, which is a type of physical dormancy that regulates germination over time by preventing imbibition until the seed coat is damaged (Baskin and Baskin 2001). It is a common survival strategy in Mediterranean annual legumes (Norman et al. 1998).

Hard seed dormancy can provide a range of ecological advantages and, in many natural systems, is an important aspect of species fitness (Nutt 2012). In Mediterranean climates, physical dormancy is most commonly broken by a well-ordered, temperature and moisture-dependent physiological process known as "seed softening" (Taylor and Revell 2002). Taylor (1988) described this process as a two-stage model, the first being a pre-conditioning stage of exposure to high temperatures. Soil surfaces in a Mediterranean climate over summer are exposed to very high temperatures (often with maximum temperatures above $60{ }^{\circ} \mathrm{C}$ ). The second stage is exposure to wide diurnal temperature fluctuation (Taylor and Revell 2002). The result is that the seed coat becomes permeable to water, so that the hard seeds are released from dormancy gradually over the autumn. They will therefore not germinate as a result of sporadic rain events in summer. This is 
important because summer rainfall events are not commonly followed by sufficient timely rainfall to support seedling growth (Loi et al. 1999).

Furthermore, not all hard seeds will germinate in the same year; some will remain dormant but viable for future years (Loi et al. 1999). This provides a reserve seed bank in the soil, which can be crucial if there is a poor winter growing season or a major disturbance to growth, and parent plants are unable to set seed that year (Smith et al. 1998; Taylor 2005).

Legumes that form a hard seed bank have provided great resilience to the low-input farming systems of Australia as described by Donald (1965) and, more recently, Taylor (2005). When the paddock is rotated to a crop species, the seed bank remains in the soil. Those seeds that germinate in the crop are lost, but others do not germinate (and grow) until the paddock is rotated back into pasture in subsequent seasons (Loi et al. 1999). Farmers commonly rely on hard-seeded legumes to regenerate, and provide pasturage after several years of cropping, without the need for re-sowing (Taylor and Revell 2002). This strategy reduces the financial outlay required for pasture establishment, as expenditure on seed is only required for the initial introduction of the legume species and its rhizobia (Nutt 2012).

Reducing inputs and costs to agriculture is not the only benefit gained through self-regenerating pastures based upon hard seed. The farmer also has more flexibility if there is a persistent seed bank. The choice between crop and pasture for individual paddocks can be delayed into early winter, allowing for adaptation to changes in economic or environmental conditions (Revell et al. 2013).

\subsection{The inherent weakness of ley farming with annual species}

Despite historical success, and the modern improvements with the domestication of a second generation of annual pasture legumes described earlier (Loi et al. 2005), ley-farming systems based upon annual plants have severe shortcomings. In 12 recent reviews of Australian ley farming and its components, secondary salinisation of the environment and the prevalence of the summer-autumn feed gap for animal production were the most common limitations identified. Nine of the reviews highlighted the hydrological imbalance, whilst six were concerned with the feed gap. These limitations, which cover both agriculture and environment, are consistent with the challenges to sustainability defined by Crews et al. (2016). They are summarised in Table 1 and described in more detail below.

We have integrated the limitations identified by previous reviewers, and in Fig. 1, we demonstrate how each of them can be considered as part of a negative feedback loop, ultimately leading to a loss of production and profitability in both animal and crop operations. Figure 1 illustrates how the issues stem from two antecedent problems: over-reliance on a small suite of well-adapted annual plant species and a dearth of welladapted perennial plant options.

\subsubsection{The hydrological imbalance caused by annual-based farming systems}

The soils of the research region in WA where this review is focused are predominantly sandy at the surface, which makes them free draining and characteristically with low waterholding capacity (Moore 2001). Native plant communities of these regions consist of both annual and perennial species which have evolved to survive in these soils by having very long taproots to access water at depths greater than $2 \mathrm{~m}$ (Hobbs et al. 1995). Most introduced annual pastures and crops have shallow roots unable to access water and nutrients below $50 \mathrm{~cm}$ (Hamblin and Hamblin 1985). Their short growing season also means they are only using water for relatively short periods of time when compared to the (predominantly perennial) original native vegetation. When annual crops and pastures are used exclusively in agriculture, the transpiration is effectively reduced whilst the rainfall remains the same (Cocks 2001). As the rainfall exceeds the transpiration level, the hydrological balance is no longer in equilibrium and the water table rises (Hatton et al. 2002). The rising water table mobilises salts that have accrued in the soils over millions of years and brings them to the surface (Smith 1962). Dissolved salts lower the osmotic potential of water in the soil solution, and this increases the energy input required by the plant to acquire water, effectively making the water less available (Clarke et al. 2002). The soil quality and plant beneficial microbe communities can also be considerably disturbed by the salt, further disrupting the ability of plants to obtain nutrients (Lefroy et al. 1993). The PSMEIC (1998) report estimated that 15 million hectares of WA is at risk of salinity which will not only reduce the amount of agricultural land available but also threaten the functionality and biodiversity of all ecological systems, along with water quality and infrastructure (Lefroy et al. 1993).

Perennial plants in agriculture can utilise water over summer through deep roots, in a manner that more closely resembles the original flora of Western Australia (Hobbs et al. 1995) that of the Quercus/Oleaceae extensive grazing regions of southern Europe and the Acacia caven-dominated "espinal" of central Chile (Ovalle et al. 1990). Their deeper root systems also keep the subsoil dry by utilising the intermittent rainfall during spring and summer (Loi et al. 2005). This creates a dry soil "buffer" which reduces the amount of water and nutrients that drain away when they are in excess of the plants' requirements (Dear and Ewing 2008). Thus, perennial plants can theoretically maintain the hydrological balance, aiding in the reduction of dryland salinity (Caccetta et al. 2010). Not all perennial species will make the same contribution to 
Table 1 A summary of the major limitations to sustainability that have emerged in ley farming in the wheatbelt region of Western Australian, compiled from recent reviews

\begin{tabular}{|c|c|c|c|c|c|c|}
\hline & $\begin{array}{l}\text { 1. Feed gap for } \\
\text { stock }\end{array}$ & $\begin{array}{l}\text { 2. Low } \\
\text { biodiversity }\end{array}$ & $\begin{array}{l}\text { 3. Increased use of } \\
\text { nitrogen fertiliser }\end{array}$ & $\begin{array}{l}\text { 4. Inorganic } \\
\text { waste runoff }\end{array}$ & $\begin{array}{l}\text { 5. Herbicide and pesticide } \\
\text { resistance due to overuse of } \\
\text { agri-chemicals }\end{array}$ & $\begin{array}{l}\text { 6. Secondary } \\
\text { salinisation }\end{array}$ \\
\hline $\begin{array}{l}\text { Howieson et al. } \\
\text { (2000) }\end{array}$ & $*$ & * & * & & * & $*$ \\
\hline Cocks (2001) & $*$ & & & & & $*$ \\
\hline $\begin{array}{l}\text { Bathgate and } \\
\text { Pannell (2002) }\end{array}$ & & & & & & $*$ \\
\hline Dear et al. (2003) & $*$ & * & & & & * \\
\hline Loi et al. (2005) & & * & & & $*$ & * \\
\hline $\begin{array}{l}\text { Nichols et al. } \\
\text { (2007) }\end{array}$ & & * & & $*$ & $*$ & $*$ \\
\hline $\begin{array}{l}\text { Robinson et al. } \\
\quad(2007)\end{array}$ & $*$ & & & & & $*$ \\
\hline $\begin{array}{l}\text { Dear and Ewing } \\
\text { (2008) }\end{array}$ & & & & & & * \\
\hline Moore et al. (2009) & $*$ & & & & & \\
\hline $\begin{array}{l}\text { Hochman et al. } \\
\text { (2013) }\end{array}$ & & * & $*$ & $*$ & $*$ & \\
\hline Brock et al. (2013) & & & $*$ & $*$ & $*$ & \\
\hline
\end{tabular}

*Indicates that the corresponding issue was raised by the review

hydrological balance, but if the plants are deep rooted, growing throughout the year and producing aboveground biomass, it is considered they are having a positive effect (Suriyagoda et al. 2013).

\subsubsection{The feed gap in annual ley-farming systems}

The feed gap in Mediterranean farming systems is defined as a period of the year when the forage available (either quality or quantity) does not meet the demands of the livestock. Whilst the magnitude of the feed gap can be irregular, as a result of variation between years in terms of pasture growth (Bathgate and Pannell 2002), true Mediterranean climates that operate without perennial-based feed supply have a regular feed gap from late spring until autumn (Moore et al. 2009). During this time, the farmer must produce or purchase conserved fodder and grain to supplement senesced crop and pasture residues or reduce their livestock population (Suriyagoda et al. 2013). The quality of standing forage declines after senescence as the plant matter decomposes, particularly after rainfall events (Bathgate and Pannell 2002). This makes it challenging to rely solely on senesced in situ biomass to provide the feed and, as it is of low quality, the livestock production is restricted (Kaiser et al. 2007). Wool quality suffers a severe reduction as a result of nutritional decline in the feed available to sheep during the feed gap. This provides a significant challenge to the industry in loss of production in livestock and general profitability (Hacker et al. 2009).
As the feed gap in these agricultural systems is a regular and predictable feature, farmers have adapted to manage their stocking rates and lambing time to limit the impact of the stress (Moore et al. 2009). By keeping the livestock populations below a conservative level, the difference between the amount of feed available and feed required during the gap is decreased. Through this process, livestock can also make the most of abundant food during the spring flush of plant growth so they are entering the feed gap in the best possible condition (Bell et al. 2008). This management strategy, though widely employed, still imposes tight restrictions on the productivity of the livestock operation and is a sub-optimal strategy. It is very inefficient for animals to lose weight and then to regain it at a later stage (Byrne et al. 2010).

There is a strong case to develop pasture plants that are actively growing in the dry months and available as forage to fill the feed gap. Annual forages that are summer active have not been widely adopted in WA because they are considered high risk and are rarely economically viable (Moore et al. 2009). Because perennial plants continue to grow over the summer months, green forage may be provided for livestock during the key feed gap, greatly diminishing the input costs to animal enterprises (Byrne et al. 2010) and increasing flock health. This includes the supply of vitamin $\mathrm{E}$ which is a common deficiency in animals maintained on dry feed (Norman et al. 2013). Medicago sativa fills this niche on fertile and alkaline soils of south-eastern Australia (Dear et al. 2003) and much of the developed world (Small 2011) but fails where soils are acidic (Bouton and Sumner 1983). 
Fig. 1 A demonstration of how each issue raised by previous reviews of sustainability of ley farming in southern Australia is related: blue denotes the issues commonly raised in reviews examined in the table; yellow denotes source issues that we suggest are antecedent to the following issues; red denotes the final outcome

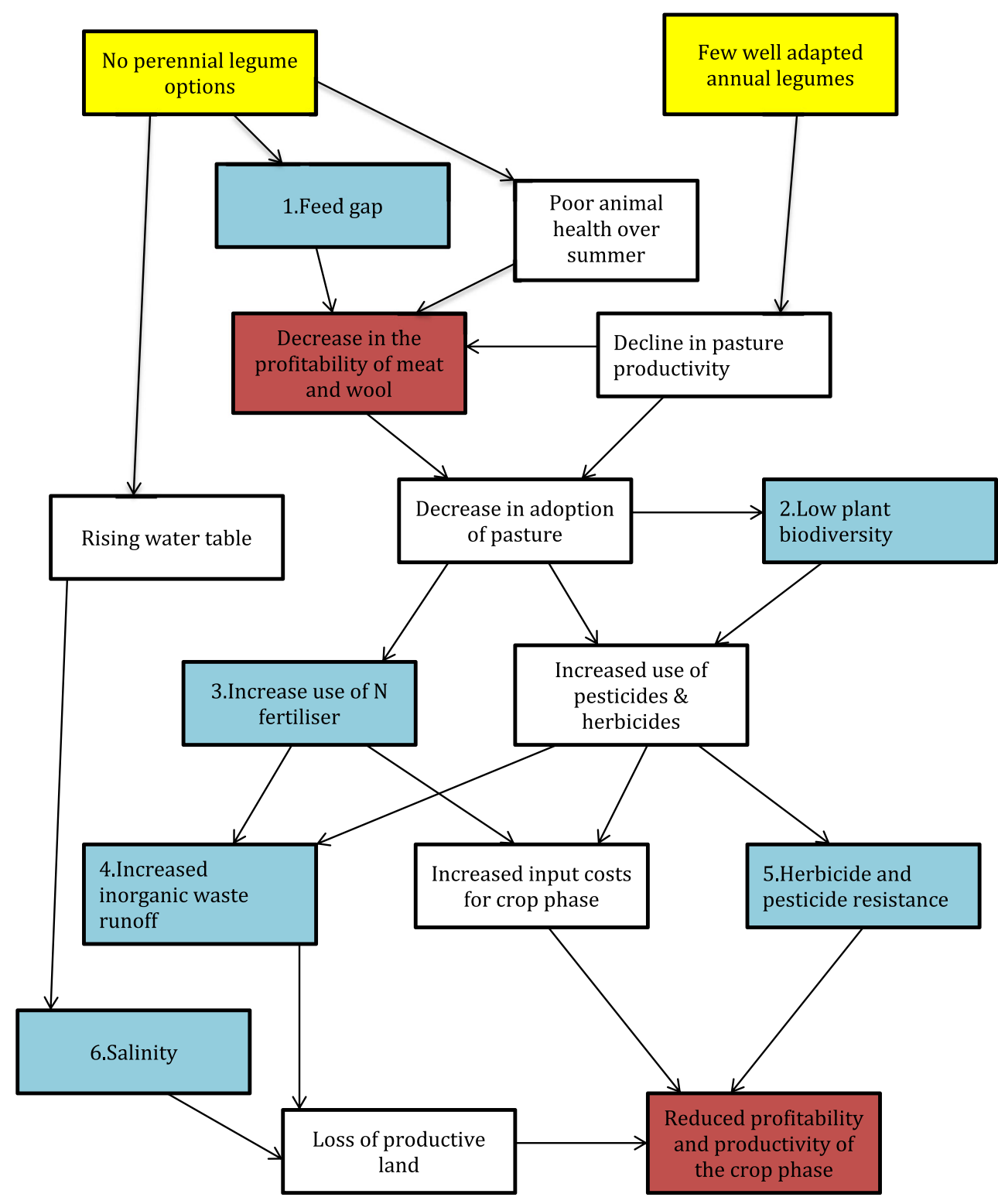

\subsubsection{Susceptibility to false breaks}

In a Mediterranean climate, a false break refers to late summer/early autumn rainfall that is sufficient to cause germination of the annual plant seed bank. If there is insufficient follow-up rainfall, these seedlings will fail to establish, thereby markedly reducing plant density in that season, with serious implications for pasture production and extending the autumn feed deficit. In an analysis of the timing and frequency of false breaks, Chapman and Asseng (2001) found that false breaks occur 2 out of every 3 years in WA. Perennial-based pastures, by contrast, are not affected, or actually benefit from these unseasonal rainfall events (Turner and Ward 2002).
Changing rainfall patterns and increased climate variability are likely to further increase the frequency of false breaks (Revell et al. 2013). In the south west of Western Australia, rainfall has declined by $10 \%$ over the last 30 years (Watterson et al. 2007). Increasing sea surface temperatures are likely to alter the variability of rainfall distribution and intensity (Sudmeyer et al. 2016). It is predicted this will lead to intense isolated summer and autumn rainfall events occurring more frequently (Hope et al. 2015). Revell et al. (2013) recommend that there must be a sustained investment in plant improvement research to address the challenges created by a more variable climate. 


\section{Developing an ecological approach to select suitable perennial pasture legumes for ley farming}

Despite the obvious benefits in overcoming the above constraints, there is no perennial pasture legume in agricultural commerce that is adapted to acidic and infertile soils, in marginal lands, such as those found in WA (Monjardino et al. 2010). Like most legumes in global agriculture, the suite of perennial pasture legumes so far domesticated is better adapted to the fertile soils of the planet, reflecting those on which humans first farmed (Howieson 2015). Many alternative perennial pasture legumes have been assessed for use in the target regions of Australia over the last half-century. Despite consensus on the importance of perennial legumes in agriculture and a recent considerable research effort ( $\mathrm{Li}$ et al. 2008; Raeside et al. 2012; Real et al. 2012), there has been no commercial success. In attempting to understand this failure, we evaluated recently researched pasture legumes against a set of attributes, informed by the literature (Table 2), that we consider should be applied in domesticating new perennial pasture legumes for difficult soils. None of the perennial legumes evaluated over the last few decades appear to have been selected on the basis of this well-documented set of attributes, including high seed yield, ease of seed harvest and symbiotic tolerance to infertility. A good example is Hedysarum coronarium. Despite being a valuable long-lived herb in WANA and parts of the Mediterranean basin, it lacks acid tolerance and its seed is very difficult to harvest and to process (Yates et al. 2006).

We conclude that (in the context of recent outcomes) to successfully develop perennial pasture legumes for difficult soils and modern farming enterprises, we must overcome three main limitations inherent in the traditional research approach. These limitations are as follows:

1. A lack of focus upon selecting new plants adapted to the least profitable cropping soils, where they might be more readily adopted and where their fiscal risk of implementation failure is lower.

2. A continued focus upon collecting germplasm from traditional sources, such as the Mediterranean basin, rather than considering alternate regions where plants with the key attributes listed in Table 2 may be discovered.

3. A belief that extant farming systems should be altered to accommodate perennial pasture species, rather than researching ways to incorporate perennial legumes into the existing systems.

We believe that by addressing these three limitations a more ecologically driven approach can be implemented, and this will ultimately be more fruitful.
As an example of how this selection approach has been employed, we introduce a new species, Lebeckia ambigua.

L. ambigua is a perennial legume native to the heathlands of the Fynbos biome in the Western Cape region of South Africa (Le Roux and Van Wyk 2007). Plants are commonly found in isolated pockets of acidic, infertile sandy soils, in regions receiving winter rainfall of between 250 and $500 \mathrm{~mm}$ (Howieson et al. 2013). L. ambigua is currently being assessed to determine if it can be domesticated as a perennial forage legume in WA (and potentially other edaphically similar regions of the world). This species is just one candidate from the region with agricultural potential identified through this process. We believe there are many other species and genera of legumes worthy of further development and examination (Muller et al. 2017; Howieson et al. 2008)

\subsection{Tackling the first limitation-selecting pasture plants for marginal lands that are least profitable for cropping}

Notwithstanding the hypothesis that the current suite of perennial pasture legumes in commerce is edaphically better suited to the fertile soils (Howieson 2015), we believe there are three main arguments to support the search for new perennial legumes for the least profitable soils.

Firstly, there is an environmental argument. In WA, the least profitable soils are undoubtedly the infertile deep sands. They are non-wetting, acidic and infertile; have low clay content, low OM and low CEC; and thus, represent a considerable challenge to modern farming. Cropping these soils rarely returns a profit and grazing the often meagre pastures renders them prone to soil erosion when the plant cover is removed (Hamblin 1987). Establishing perennial plants to better manage the erosion risk on these soils has been attempted with the importation of woody species such as tagasaste (Cytisus proliferus) (Wiley et al. 1994) for lower rainfall and Tasmanian blue gum (Eucalyptus globulus) in the higher rainfall regions (Sudmeyer and Simons 2008). These examples demonstrate that focusing on the least profitable soils where there is a lack of commercial options can lead to a rapid uptake of more sustainable practices.

Secondly, there exists an economic imperative. Despite the implementation of the perennial species mentioned above for environmental reasons, they have rarely provided an economic advantage. Tagasaste is not well suited for sheep farming, cannot be established reliably from seed and becomes woody with age and problematical (Edwards et al. 1997). Sudmeyer and Simons (2008) considered that Tasmanian blue gums were unsuited to medium rainfall agroforestry due to their sub-economic growth rates and significant losses to adjacent production through competition. Soil management methods for these sands, such as topdressing clay, can ameliorate the constraints, reduce the environmental risk and increase the 


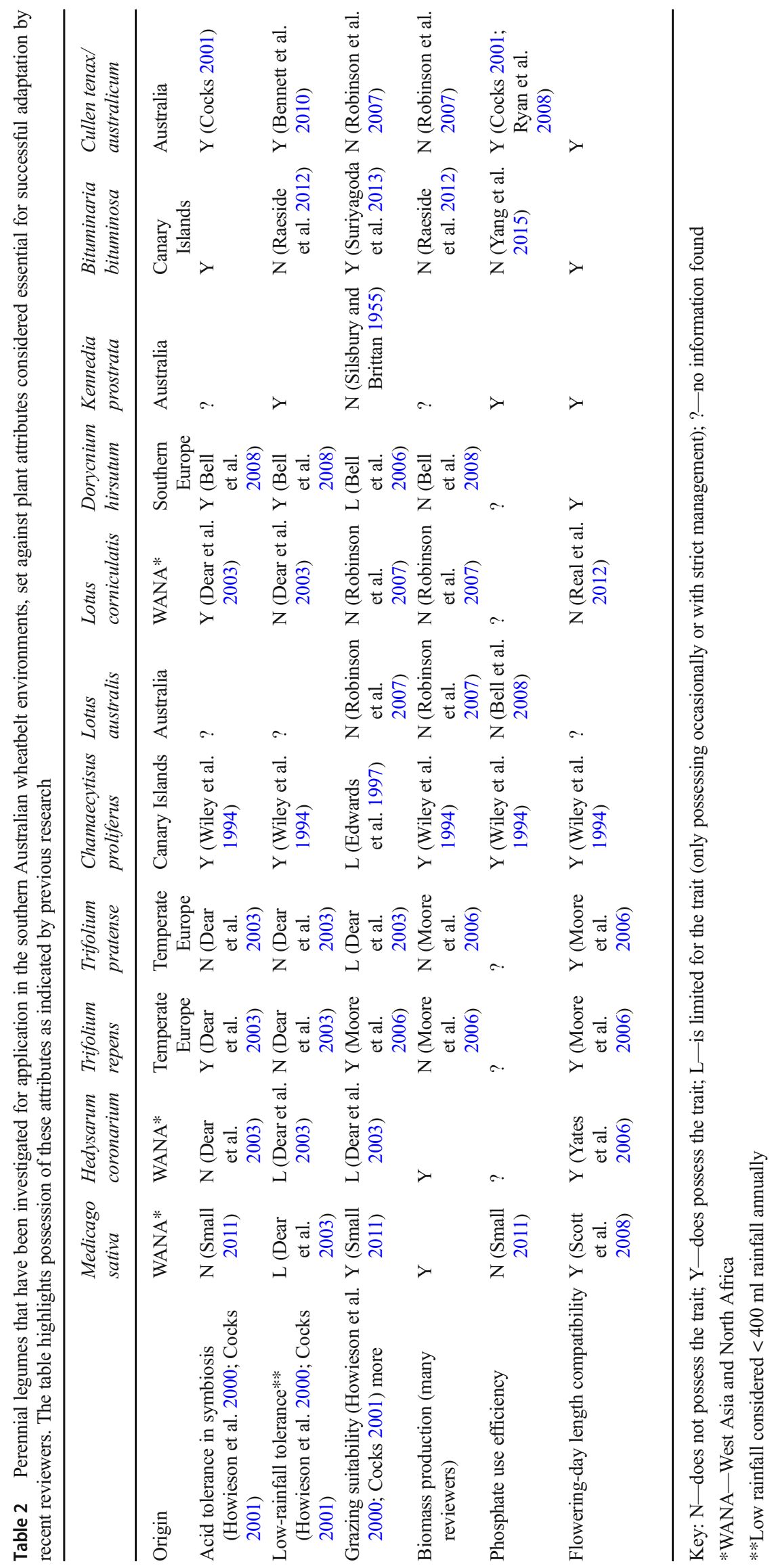


reliability of annual-based farming (Hall et al. 2010). However, this is an expensive approach and many reliable seasons are required to remunerate the investment (Roper et al. 2015).

The third key reason is the opportunity for social return. Global food security is reliant on increasing production on soils with significant edaphic constraints, whilst safeguarding the natural resource base (Sanchez et al. 1997). Increasingly, the soil fertility of marginal lands is depleted through unsustainable practices (Sanchez 2002). Rebuilding fertility through high-input soil management technology (such as mineral fertilisers) is often not feasible, as most often these marginal agricultural lands are retained by famers with limited resources (Sánchez and Salinas 1981). These farmers are often unable to make these investments due to prohibitive costs and the increased risk of return brought by the variability in yields (Sánchez and Salinas 1981).

Taken together, these limitations suggest that low-input methods of amelioration, such as planting species that are tolerant of existing soil constraints, and which can biologically improve nutrition, are required to replenish soil fertility (Sánchez and Salinas 1981). Only through better preservation of soil resources can poverty be reduced and food security be attained (Sanchez et al. 1997).

\subsection{Tackling the second limitation-from where to source new plant germplasm?}

There are five major regions of the world with Mediterraneantype climates: the Chilean coast, the Mediterranean basin, the Western Cape of South Africa, southern Australia and the Pacific Coast of North America (Reinten and Coetzee 2002). The Mediterranean basin in the northern hemisphere has been the predominant source of germplasm for agricultural pasture species improvement in Australia for over a century (Howieson et al. 2000). Annual species dominate the herbaceous component of the Mediterranean basin, but it is important to note that the infrequent perennial legumes therein are confined to the more fertile soils and higher rainfall regions (Cocks 2001). The low-rainfall zone of WA is not edaphically suitable for most of these perennial Mediterranean legume species when considering the multiple edaphic challenges already outlined. The lack of success demands that researchers should now investigate other regions of the world which share a "Mediterranean climate", but which are also more ecologically similar, have soils with lower fertility and carry a greater diversity of perennial species.

Several ecological reviews (Wisheu et al. 2000; Hobbs et al. 1995; Goldblatt 1997) have compared the Mediterranean-type bioclimates and concluded that the biome most closely resembling the target wheatbelt regions of WA in terms of soils, disturbance regimes and vegetation composition is the Fynbos of South Africa.
The following sections of this review will discuss the Fynbos as an alternative region from which to source new germplasm of perennial legumes and their nodule bacteria, as an example of matching edaphic similarities when seeking to develop new plants for agriculture. We then emphasise physiological attributes that we see as essential in these plants, if they are to be domesticated. Lastly, we discuss how to fit new perennial pasture plants into existing and entrenched farming systems that land managers (initially in Australia) are familiar with.

\subsubsection{The Fynbos of RSA and the wheatbelt regions of Western Australia}

The WA regions we discuss encompass some 20 million hectares of which nearly $64 \%$ is agricultural land primarily used for mixed sheep and grain farming (ABARE 2016). These regions are generally characterised as having a Mediterranean-type climate in which the rain falls mostly in the winter (Stephens and Lyons 1998). The summers are typically hot and dry for long periods in this region, and plant growth is severely limited by the lack of surface soil moisture (Hobbs et al. 1995). Native Australian plants found in these regions are typically unsuitable for use in agriculture (Cocks 2001). Because of this, Australian agriculture has a long and successful history of introducing plants such as wheat and barley from similar Mediterranean-type bioclimatic environments (Puckridge and French 1983). However, we can learn a great deal from the remnant vegetation in WA about the plant traits that might make new plant introductions for agriculture successful in this environment.

The native vegetative communities of WA are considered unique, with a very diverse range of endemic plant species (Beard et al. 2000). Amongst the remnant plant communities are those of the Kwongan heathlands, consisting of sclerophyllous shrubs. These grow on the sandy soils with the lowest fertility throughout the south west of WA (Beard et al. 2000). The Kwongan heathlands have very high levels of species richness and endemism and are considered hotspots of floral biodiversity (Beard et al. 2000). The Fynbos biome is a belt within the Western Cape of South Africa that stretches from the West of Port Elizabeth to Nieuwoudtville, north of Clanwilliam (Reinten and Coetzee 2002; Manning and Goldblatt 2012; Mucina et al. 2006). The Fynbos, like the Kwongan heathlands, exhibits rich botanical diversity, and salient to this review, the biome boasts a very large diversity of perennial legumes. There are 795 legume species from 45 genera native to the Fynbos, of which the majority are endemic (Manning and Goldblatt 2012). Seven species from five genera are trees, 21 species from five genera are annuals but the vast majority (767 species from 39 genera) are shrubs, pyrophytic suffrutices or perennial herbs (Manning and Goldblatt 2012). 
The soils of both regions are ancient and derive from similar parental material (Hobbs et al. 1995). Processes of weathering have yielded coarse-grained sand soils, with very little clay content and a lack of water-holding capacity (Goldblatt 1997). Although acid sandy soils derived from Table Mountain Sandstone are typical for the Fynbos, some parts have acid clay soils derived from granite or alkaline limestone soils (Mucina et al 2006). The sandy soils of the Kwongan heathlands and the largest part of the Fynbos biome are also relatively poor in nutrients compared to the other Mediterranean-type regions (Wisheu et al. 2000). The low availability of nutrients, particularly phosphorous, is limiting to plant growth and significant in the type of vegetation that can be supported (Goldblatt 1997).

The similar challenge posed by their edaphic circumstances is considered the major reason that the floral communities of the Fynbos and the Kwongan are comparable (Wisheu et al. 2000). The remarkably low nutrient availability constrains the growth of the vegetation, and sclerophylous shrubs are the principal life form for both regions (Wisheu et al. 2000). Extensive and deep root systems are also required to access water and nutrients on the freely draining soils, so generally only plants with large tap roots and specialised structures are able to thrive (Hobbs et al. 1995). Lebeckia ambigua provides a good example of this specialised root architecture. It possesses a tap root capable of penetrating $3 \mathrm{~m}$ into the soil profile and can produce cluster roots (Edwards 2015). Cluster roots arise when portions of lateral roots become highly branched, forming many closely spaced hairy roots (Raven et al. 2005). These specialised root zones are capable of forming associations with beneficial bacteria and releasing exudates that aide in the uptake of nutrients (Lambers et al. 2006).

Taken together, we contend that this set of circumstances indicates that the Fynbos biome offers a potential valuable resource for domestication of new plant species for agriculture. However, a further key part of domestication of new plants for pasture-ley systems is whether the plants are adapted to grazing by ruminants.

\subsubsection{Grazing pressure in the Kwongan and the Fynbos}

One manner in which the plants in the Kwongan and Fynbos do differ, and which is critically relevant to pasture plant domestication, is in their interaction with grazing animals. Many native Australian legumes contain toxins that deter grazing by animals (Dowling and McKenzie 1993). Gastrolobium, Gomphelobium and Oxylobium are common genera in WA and contain species which produce the toxic compound sodium monofluoroacetate (Short et al. 2005). Native animals have co-evolved with these species, developing a resistance to the compound (Short et al. 2005). The compound is lethal to introduced herbivores, including agricultural species, and therefore, plants that produce sodium monofluoroacetate are completely unsuitable for grazing. Other native legumes in Australia which do not contain sodium monofluoroacetate, such as that found in the Kennedia genus, have their growing points exposed, and whilst they tolerate browsing, they do not tolerate sustained grazing (Silsbury and Brittan 1955). They are also generally slow growing and therefore relatively unproductive (Robinson et al. 2007). In contrast, a large diversity of ruminants and browsers, both native and introduced, have grazed the Fynbos vegetation (Radloff et al. 2014). Though it has been poorly studied, herbivory has had an important influence on the vegetation structure and development of the Fynbos through its evolution (Kraaij and Novellie 2010). Some legumes of the region accumulate quinolizidine and pyrrolizidine alkaloids and are therefore poisonous to various degrees (Van Wyk 2003), whilst a small minority (e.g. Lotononis species) are strongly cyanogenic and potentially lethal to livestock (Van Wyk 1989). However, free grazing by agricultural ruminants introduced to the Fynbos in current times provides a high intensity of grazing pressure on the native vegetation without adverse effects to livestock health (Radloff et al. 2014). Therefore, the Fynbos appears to be an ideal place to search for perennial legume species that are amenable to grazing by agricultural animals, and are adapted to infertile soils.

As previously discussed, to improve the sustainability of ley-farming systems, perennial pasture legumes are required to reduce the summer-autumn feed gap in WA. Therefore, any new legume must be productive during autumn and safe and nutritious for livestock to consume. Preliminary experiments have shown L. ambigua to be capable of modest forage production during the autumn on the target soils. In the months of February-June 2016, replicated $50 \mathrm{~m}^{2}$ swards of L. ambigua produced $1.3 \mathrm{t} / \mathrm{ha}$ of dry matter in the target wheatbelt region of WA, in the absence of any recorded rainfall. In comparison, M. sativa produced $0.3 \mathrm{t} /$ ha during the same period. Lebeckia ambigua has similar in vitro feed qualities to $M$. sativa (Table 3).

\subsection{Tackling the third limitation-selecting perennial pasture plants that will complement current farming systems}

We identified a third major weakness in the contemporary research approach to domestication of perennial pasture plants for the WA regions - that of attempting to mold farming systems to fit the plant. Globally, perennial legumes are grown in high-input agricultural systems that can operate successfully within the framework of a high cost of establishment, where outputs are also high. However, the significant and ongoing costs associated with establishment of perennial plants are a considerable barrier to their adoption in the low-rainfall environments in WA. To obviate these high establishment costs, Cocks and Bennett (1999) suggested that "phase farming" 
Table 3 The nutritive value of $L$. ambigua dry leaf and stem material from in vitro analysis. Dry matter was collected from trial plots in West Dale, Western Australia during March-June

\begin{tabular}{lcc}
\hline Nutritive value & Leaf & Stem \\
\hline Dry matter (\%) & 92.9 & 93.7 \\
Crude protein (\%) & 23.1 & 13.1 \\
Neutral detergent fibre (\%) & 34 & 57 \\
Acid detergent fibre (\%) & 21.9 & 44.1 \\
Acid detergent lignin (\%) & 8.5 & 10.2 \\
Ash (\%) & 8.7 & 5.7 \\
Organic matter (\%) & 91.3 & 94.3 \\
Digestible dry matter (DM) (\%) & 81 & 54.7 \\
Digestible organic matter in DM (\%) & 75.5 & 53.2 \\
Metabolisable energy (MJ/kg DM) & 12.3 & 7.8 \\
Water-soluble carbohydrates (\%) & 9.47 & 6.4 \\
\hline
\end{tabular}

could replace ley farming as an effective system for incorporating perennial legumes, where the forage phase is re-sown after each cropping period. However, this has proven commercially unattractive as it appears too expensive and timeconsuming to re-sow perennial plants in low-input/low-output systems.

In addressing the third weakness in approach, we need to focus on which physiological and reproductive elements of perennial legumes (as they have evolved in their natural systems) might coincidentally suit them to modern farming systems. In the Fynbos, annual species rarely persist, and the flora is dominated by perennial shrubs (Rutherford et al. 2011). As outlined above, nearly $97 \%$ of the 795 Fynbos species are shrubs or perennial herbs. Charnov and Schaffer (1973) consider that a perennial habit should be favoured in such environments, where there exists low juvenile survivability. These environments can inhibit recruitment in each annual cycle, regardless of how many seeds are produced (Charnov and Schaffer 1973). An established perennial plant can, nevertheless, set seed every year it persists, increasing the opportunity that 1 year will be favourable to more successful recruitment, or a disturbance event will occur to increase seedling establishment (Pierce and Cowling 1991). This is a key consideration as we explore characteristics in perennials that might make them suitable for the low-rainfall farming systems of the world.

\subsubsection{Understanding disturbance and opportunities for recruitment}

Fire is considered the major disturbance regime of the Fynbos, exerting a significant influence on the structure and function of the floral community (Rutherford et al. 2011). Two main strategies are employed by plants to thrive in fire-prone environments: re-sprouting from undamaged tissues (re-sprouters) or recruiting from seed (seeders) after the fire (Atwell et al. 1999). Species that have the ability to re-sprout have welldeveloped underground carbohydrate stores in the form of lignotubers, which are protected from the fire. After the fire destroys the vegetation aboveground, the stores are activated and the plant regrows (Atwell et al. 1999). Seeders either rely solely (obligate) or partially (facultative) on recruiting from seed, post-fire (Wisheu et al. 2000).

The re-sprouting strategy is certainly the dominant mechanism encountered across the majority of the known fire-prone environments (Pausas and Keeley 2014). However, this dominance is reversed in both the Fynbos and Kwongan communities. Species that are able to regenerate from seed are more frequently encountered in these biomes, along with the only occurrence of obligate seeder species (Wisheu et al. 2000). Less than $25 \%$ of Fynbos legumes are sprouters (Le Maitre and Midgley 1992) and re-sprouting is not evenly distributed amongst genera. As an example, all 19 species of Rafnia (Campbell and Van Wyk 2001) and 12 of the 14 species of Lebeckia (Le Roux and Van Wyk 2009) re-sprout after fire. Lebeckia ambigua has both re-sprouting and re-seeding capacity after fire. Can this key property be exploited in agriculture?

Fire disturbance removes all of the aboveground vegetation which had been competing for, and accumulating, the water and nutrients in the post-fire interval (Moreno and Oechel 1994). Some of the nutrients in the ecosystem are returned to the soil after the fire; hence, the ecosystem post-fire has little competition for light and moisture but with relatively fertile soil available for whichever species is the first to regenerate. The chance of juvenile survival is at its highest post-fire. Seeds are small and only need a small amount of water to germinate and are able to grow quickly to make the most of the favourable conditions (Pierce and Cowling 1991; Le Maitre and Midgley 1992). A parallel disturbance in agriculture might be a cropping phase. There is also evidence from extant species that obligate seeders have physiological traits which make them more tolerant of drought and water stress (Pausas and Keeley 2014). In Fynbos legumes, however, there is a tendency for seeders to favour moist habitats, whilst sprouters are more commonly encountered in dry or seasonally arid places (Schutte et al. 1995).

The more seed a seeder species is able to produce during a fire interval, the higher its chances of successful recruitment (Wisheu et al. 2000). For this reason, the life cycle of a seeder species must closely correlate to the fire interval (Wisheu et al. 2000). Less predictable regimes and long periods are seen to be detrimental to this regeneration strategy (Rutherford et al. 2011). Pierce and Cowling 1991 discovered that the longer the interval between fires, the smaller the germinable soil seed "bank", and the less the seed bank represents the aboveground vegetation. The ideal disturbance regime for the obligate seeder species is a predictable, short interval. In the context of this 
review, a short interval before fire disturbance causes death might be seen as analogous to the kind of pressure that would be put on agricultural plants in a cropping phase.

Production of large amounts of harvestable seed is a very desirable feature in plants sought for agricultural domestication (Howieson et al. 2000), but unfortunately, this trait is considered very rare in herbaceous perennial species (DeHaan and Van Tassel 2014). Inadequate seed production is considered one of the major obstacles to the widespread agricultural adoption of many forage cultivars, both annual and perennial (DeHaan and Van Tassel 2014). High fecundity is more associated with an annual life strategy in plants, because they have only one reproductive opportunity before death (this is termed semelparity). Therefore, there is evolutionary pressure to allocate more resources into seed production (Pausas and Keeley 2014). The unusual combination of herbaceous perenniality with high fecundity does, however, occupy an ecological niche in environments with regular fire disturbance and low juvenile survivability, such as the Fynbos and Kwongan heathlands.

Thus, we offer an alternative vision for domesticating perennial legumes into agriculture: that by selecting species which produce large quantities of seed and that are suited to the edaphic constraints of the marginal lands in the lowrainfall zones of WA, we might be able to develop a "perennial ley-farming system". The perennial plant in this system would persist for several years and, during this period, produce a seed "bank" with large numbers of seeds. After a period of production and soil fertility improvement, the land-owner might provide disturbance by rotating the perennial pasture with one or several crops and, in the process, completely remove the perennial plants. However, after a period of cropping, the perennial legume would recruit from its seed bank to reform the perennial-based pasture. To restore biological $\mathrm{N}$ into the disturbed system, it would nodulate with resilient rhizobia previously introduced to the soil.

We expect farmers would adopt such a system for its biological, social, ecological and economic advantages. We now explore some of the key attributes of such a perennial plant ideotype further.

\section{Hard seed produced by perennial legumes and its potential exploitation in perennial ley-pasture systems}

If we are to learn the lessons from the commercially successful annual pasture-ley system, we would seek plants that produce a large quantity of seed, and develop a long-lived seed bank in the soil. Indeed, our previous research has strongly emphasised that plant ideotypes for domestication into leyfarming systems should produce large quantities of hard seed (Table 2) (Howieson et al. 2000).
Hard seed dormancy is found at low levels in the few domesticated perennial pasture legumes from temperate regions occasionally employed in agriculture (Baskin and Baskin 2001) (Table 4). However, this trait is not exploited. This may be because, whilst the seed produced by these perennial plants can be hard, the number of seeds is relatively low, i.e. they are not prolific seeders, and seedlings can be uncompetitive. Thus, the few perennial legumes currently in established farming systems are re-sown after each crop phase (Ward 2006). This is described as "phase farming" (vis-à-vis ley farming).

Current forms of phase farming with perennial species are thus very different to ley farming, in that the seeds produced by the perennial legumes do not form a viable hard seed bank. The phase ends when the legume is mechanically or chemically removed, and a cropping phase can then be implemented to access the biologically fixed nitrogen (Cocks and Bennett 1999). The subsequent (perennial) legume phase must then be re-established by sowing scarified seed, at considerable cost (Kimura and Islam 2012). Added to this economic disincentive, post-harvest seed processing is difficult and time intensive, significantly increasing the price of seed for many cultivars of perennial legumes (Ewing et al. 2006). A typical example is Hedysarum coronarium. It produces a low yield of seed per hectare and the pod structure makes the retrieval and processing of seed very labour intensive (Ewing et al. 2006). Hence, the seed is very expensive and this is one reason why adoption of this species is low in the WA (another is that it is not well adapted to acid, sandy soils). For the perennial phase in current farming systems to be profitable, the cost of establishment must be recovered over a few years (Yates et al. 2006) compared to the standard 10-20 years when a pasture is regenerating from a hard seed bank in the annual ley system.

Parenthetically, selecting perennial species with high seed yields that can be mechanically harvested (and therefore inexpensive) may be a strategy to increase the economic viability of current phase systems, even without seeking species that produce hard seed. The potential to harvest seed from the legume creates a viable income stream, whilst also allowing the growers to produce their own seeds to reduce the cost of establishment (Howieson et al. 2000). This feature is lacking in all of the current perennial pasture options for low-rainfall regions of WA. For example, the lucerne (Medicago sativa) seed market in Australia is highly lucrative, with RIRDC (2014) estimating its worth at AUD \$59.3 million per year. However, seed crops of lucerne are generally grown under irrigation and with high-intensity production regimes. Eighty-three percent of all lucerne seed production in Australia is grown in Keith and neighbouring regions of South Australia (Anon 2010). These areas enjoy significantly higher rainfall and more productive soils than the low-rainfall regions of WA, where traditionally, the fecundity of lucerne is too low to establish a viable seed crop (Cocks 2001). In 
Table 4 Initial hard seed dormancy for legume species commonly encountered in Mediterranean agricultural systems. The breakdown of dormancy under field conditions is listed for those species that have been studied. References are reported relating to each of the studied species

\begin{tabular}{|c|c|c|c|c|c|}
\hline Species & $\begin{array}{l}\text { Life } \\
\text { form }\end{array}$ & $\begin{array}{l}\text { Initial } \\
\text { dormancy } \\
(\%)\end{array}$ & $\begin{array}{l}\text { First summer } \\
\text { dormancy }(\%)\end{array}$ & $\begin{array}{l}\text { Second summer } \\
\text { dormancy }(\%)\end{array}$ & Reference \\
\hline $\begin{array}{l}\text { Trifolium } \\
\text { subterran- } \\
\text { eum }\end{array}$ & Annual & 98 & 37 & 18 & Loi et al. (1999) \\
\hline $\begin{array}{l}\text { Ornithopus } \\
\text { sativus }\end{array}$ & Annual & $97-99$ & 85 & 60 & Nutt (2012) \\
\hline $\begin{array}{l}\text { Biserrula } \\
\quad \text { pelecinus }\end{array}$ & Annual & 99 & 98 & 83 & Loi et al. (1999) \\
\hline $\begin{array}{l}\text { Medicago } \\
\text { sativa }\end{array}$ & Perennial & $30-40$ & 10 & Not studied & $\begin{array}{l}\text { Pang et al. (2009), } \\
\text { Kimura and Islam } \\
\text { (2012) }\end{array}$ \\
\hline $\begin{array}{l}\text { Trifolium } \\
\text { repens }\end{array}$ & Perennial & $85-95$ & $10-20$ & Not studied & Harris et al. (1987) \\
\hline $\begin{array}{l}\text { Bituminaria } \\
\text { bituminosa }\end{array}$ & Perennial & 70 & 0 & Not studied & $\begin{array}{l}\text { Pang et al. (2009), } \\
\text { Castello et al. (2013) }\end{array}$ \\
\hline $\begin{array}{l}\text { Lotononis } \\
\text { bainesii }\end{array}$ & Perennial & 80 & Not studied & Not studied & $\begin{array}{l}\text { Pang et al. (2009), Real } \\
\quad \text { et al. (2005) }\end{array}$ \\
\hline $\begin{array}{l}\text { Lotus } \\
\quad \text { corniculat- } \\
\quad \text { us }\end{array}$ & Perennial & 94 & Not studied & Not studied & $\begin{array}{l}\text { Pang et al. (2009), } \\
\text { Ollerton and Lack } \\
\text { (1996) }\end{array}$ \\
\hline $\begin{array}{l}\text { Lebeckia } \\
\quad \text { ambigua }\end{array}$ & Perennial & 93 & 83 & 53 & This review \\
\hline
\end{tabular}

contrast, tagasaste (tree lucerne, Cytisus proliferus) is very well adapted to the deep sandy soils in this region and produces large amounts of seed per hectare (Wiley et al. 1994), but no mechanised way of harvesting the seed exists, so labour-intensive hand harvesting is required.

It has been postulated that breeding new perennial cultivars that have a lower percentage of hard seed is crucial to ensuring plants fit economically into phase-farming systems (Ewing et al. 2006). We would argue the opposite: that no phasefarming system will be successful in our target environments unless it exploits hard seed, and thus, is better suited to the economic realities of the region.

\subsection{Is it possible to develop persistent and hard-seeded perennial pasture legumes to fit within ley-farming systems by utilising hard seed?}

Ordinarily, the place to begin this search might be within the existing suite of perennial legumes: either those commercially available or currently under research. In Table 2, we list some of the contemporary species and cross-reference them against attributes we postulate to be essential for the success in our envisaged perennial ley system. "N" in any attribute column infers a low probability of being successful in the perennial ley.

Working through Table 2, unfortunately, no single species appears suitable for use in the putative perennial ley system. Those perennials that are available:
- Are poorly adapted to the edaphic constraints of marginal lands

- Produce seed that is expensive to multiply and process, thereby making them economically unattractive

- Do not produce enough hard seed to establish a seed bank

- Possess hard seed breakdown dynamics not suited to persisting under consecutive years of cropping (and thus rotating in and out of cropping intervals is too challenging)

Lebeckia ambigua is very fecund species (it can produce 20,000 seeds per individual per year for some mature plants) and the seed produced has a very high percentage of hard seed dormancy (88-99\%) (Edwards 2015). These seed attributes of L. ambigua are quite unique when set against the most common perennial pasture legumes utilised in agriculture (e.g. Table 3). The hard seed dynamics discovered in L. ambigua are more comparable to the annual legumes used in leyfarming systems.

We postulate that L. ambigua was faced with the same evolutionary pressures to produce a large amount of seed as were the annual species of the Mediterranean basin so successfully domesticated in Australian annual ley-farming systems (e.g. Biserrula pelecinus) (Howieson 1995). Further, its life cycle evolved such that it produces as much seed as possible through growing seasons during the fire interval, to compete in an environment with low juvenile survivability. Additionally, to ensure that a high percentage of seeds germinated at the ideal time (the first rains post-fire), we suspect the 
species has evolved mechanisms to regulate germination, such as hard seed dormancy. We have begun to investigate this and, in doing so, revisited some of the original collection sites of L. ambigua in 2016, a decade after the original collection of seed and rhizobia. The succession of an originally Lebeckiadominant site over this period is illustrated in Figs. 2 and 3 and provides strong lessons for managing its ecology in Western Australia (Fig. 4).

\subsection{Field softening of the hard seed of Lebeckia ambigua}

In the first field experiments in WA, L. ambigua was determined to have an initial hard seed content of $93 \%$. This reduced to $53 \%$ after 57 weeks of exposure to field conditions (Table 4). In comparison, Bituminaria bituminosa (another perennial legume that has been examined for agricultural domestication) was reported to have a primary dormancy of $70 \%$. This lasted for a period of 3 months before germination at near 100\% (Castello et al. 2013). The initial level of hard seed in L. ambigua is considerably higher than that encountered in the perennial legumes Medicago sativa (Kimura and Islam 2012) and Trifolium repens (Harris et al. 1987) and similar to Lotus corniculatus (Ollerton and Lack 1996) which are all commonly used in agriculture. No studies of field softening of hard seed have been reported with these perennial legumes, probably because an understanding of seed bank dynamics is not normally required for the agricultural management of these (or any) perennial pasture legumes.

The breakdown patterns of the hard seed of L. ambigua can be compared to that of annual legume species in ley-farming systems. Nutt (2012) reported that under field conditions, seed of French serradella (Ornithopus sativus) dropped between 20 and $30 \%$ from their initial hard seed levels of $90 \%$ over a 12 month period. Loi et al. (1999) found that after 12 months of field softening in Biserrula pelecinus, seed remained $90 \%$ hard, reducing only $8 \%$ from the initial level. In comparison,

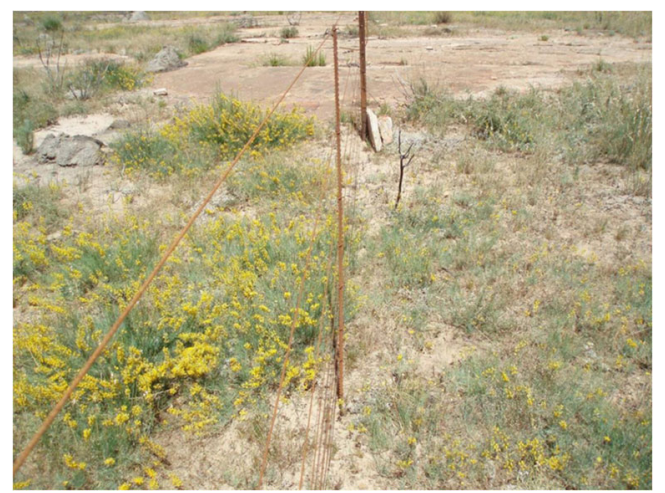

Fig. 2 An original collection site of L. ambigua near Nieuwoudtville in December 2006

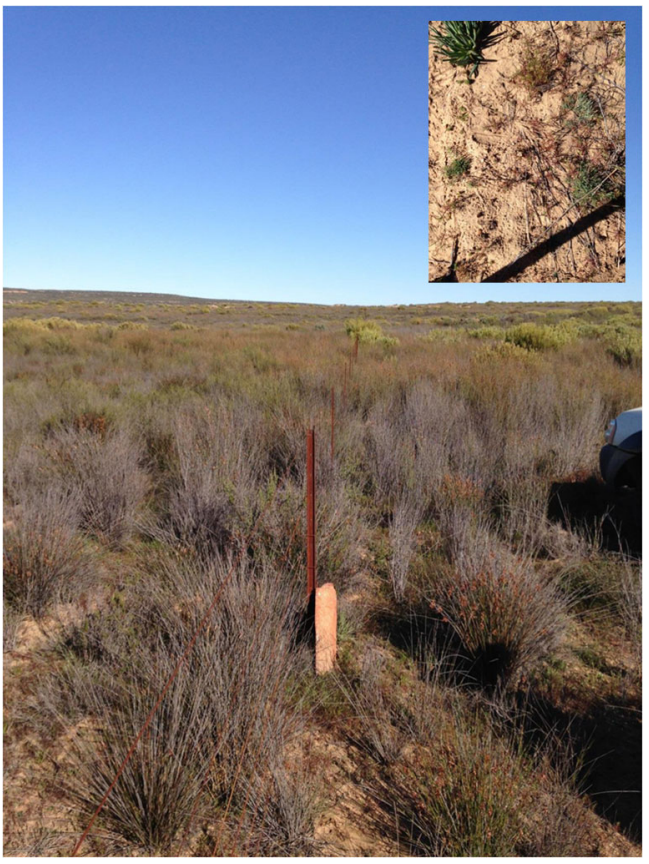

Fig. 3 The same original collection site in October 2016 illustrating species succession. Seedlings of L. ambigua were present in 2016, indicating a recent germination event as a result of seed softening (inset)

in the same study, the annual clover Trifolium subterraneum (the corner-stone of Donald's original ley-farming review) recorded an initial hard seed percentage of $98 \%$, but this dropped to $18 \%$ over 12 months (Table 4 ).

The hard seed level of L. ambigua dropped from 93 to $83 \%$ by winter after 24 weeks of field exposure during the first summer-spring softening period (Edwards 2015). Comparatively, B. pelecinus and T. subterraneum had hard seed percentages of 98 and $31 \%$, respectively, at the beginning of winter in their first year of field exposure (Loi et al. 1999). However, in that study, the seed was not placed into the field setting until autumn and, therefore, had no exposure to the summer softening environment. Further, the seeds were

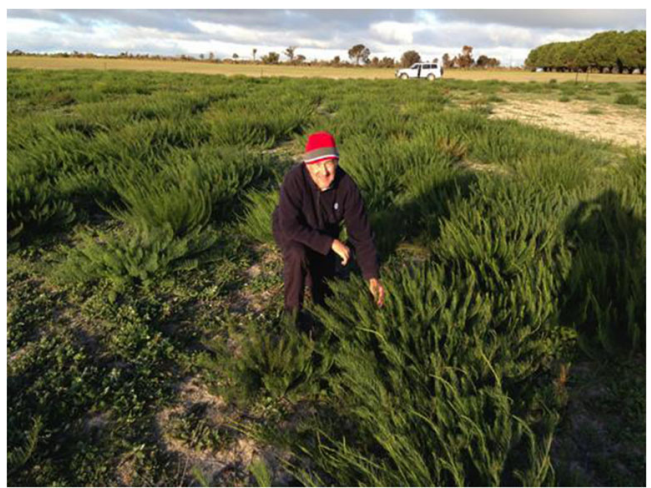

Fig. 4 Professor Howieson in a Lebeckia ambigua field trial in Harrismith, Western Australia. The trial was sown into a deep sandy soil with very low inherent fertility and water-holding capacity and a long-term average rainfall $<400 \mathrm{~mm}$ 
buried to a depth of $2 \mathrm{~cm}$, not $1 \mathrm{~cm}$ as in our study. Lebeckia ambigua, therefore, seems to uniquely behave more as a hardseeded annual legume in its seed ecology, than in the expected manner of a domesticated perennial legume.

\subsection{Further questions to be answered}

Two research questions that arise immediately are (i) can Lebeckia ambigua regenerate from a hard seed bank following cropping to create a perennial ley farming system, and (ii) can its rhizobia survive to nodulate after such a major disturbance interval?

A reserve of $53 \%$ dormant L. ambigua seed after 1 year of softening is comparable to that of the hard-seeded French serradella cultivars and significantly higher than the successful subterranean clover cultivar Dalkeith. However, whether enough seed of L. ambigua is released from dormancy in a timely manner after several seasons of accumulation to form a useful pasture phase, following disruption by a cropping event, is currently unclear. This will depend on how much seed is produced and the uniformity of its release from dormancy. These factors are likely to be different between an annual and a perennial species and require further research.

The nodule bacteria for L. ambigua are beta-rhizobia from the genus Burkholderia (Howieson et al. 2013). This is a relatively new genus to be described by legume microbiologists (Moulin et al. 2001), and little is known of its ecology (Sprent et al. 2017). There are indications that Burkholderia, particularly those from the Fynbos, favour acidic soils (Dludlu et al. 2017). Knowing that the introduction of Fynbos legumes to Australia has hitherto been compromised by the poor competitive ability of their symbionts (Gerding et al. 2012, 2013, 2014), experiments are underway to select strains of Burkholderia suitable for L. ambigua that are well adapted to the edaphic stresses of the target soils in WA.

\section{Conclusion}

To improve the productivity and sustainability of agriculture in WA, in the context of the review of Crews et al. (2016), a perennial pasture legume suitable for low-rainfall areas and very infertile soils is required. Whilst some have advocated the development of perennial grain crops, we suggest a perennial forage legume would be more pragmatic, as animals are less selective in their food preferences than humans. A perennial forage would deliver increased nutritional benefit to stock (particularly through severe summer and autumn), biological nitrogen fixation to increase soil fertility and hydrological benefits to holistically contribute to sustainability of the agro-ecosytem. Despite a considerable research effort, access to well-adapted plants is still severely limited (Dear and Ewing 2008). Although it is unilaterally agreed that the low-rainfall zone of WA is a particularly challenging environment for perennial pastures (Turner and Asseng 2005; Cocks 2001; Dear et al. 2003), we believe the approach to seeking potential candidates for domestication can be improved.

Dear and Ewing (2008) suggested that when screening new forage plants for agricultural candidacy, the establishment phase must be low risk and low cost. We concur and would add that the maintenance of the entire phase should be low cost and resilient and integrative with current farming systems. Traditional methods of establishing perennial pasture legumes require a high economic outlay on seed each time the phase is established, and this makes the practice untenable.

By identifying species that produce large amounts of hard seed, and through managing the hard seed bank, the prospect of inventing a perennial ley-farming system is potentiated. This would be superior to contemporary phase farming as it would incorporate the low-input, low-risk, highly amortised aspects of annual ley farming which makes that enterprise successful, in a challenging and highly variable environment.

The Fynbos in South Africa is an environment characterised by poor soil fertility, low rainfall, periods of drought and frequent fire disturbances. To increase the probability of survival in this environment, a number of plant species have evolved to favour a perennial life form, whilst still producing abundant seed combined with physical hard seed dormancy to regulate germination (Wisheu et al. 2000). The Fynbos appeals as a biome in which to seek new plants for agriculture on similar soils (Howieson et al. 2008), and as this concept is gaining in acceptance (Muller et al. 2017), it is appropriate to focus selection characteristics on plant traits we have proven are important for domestication (Howieson et al. 2000). The role of the symbiosis cannot be ignored, as it has previously hindered domestication attempts in plants from this region (Gerding et al. 2012).

Lebeckia ambigua is one species from this environment that demonstrates a combination of the features we consider essential: high fecundity, hard seed dormancy, symbiotic tolerance of infertility and grazing tolerance. The pattern of hard seed breakdown displayed by L. ambigua is comparable to that recorded for hard-seeded O. sativus, and B. pelecinus, annual legumes which have been successfully implemented in annual ley systems. It may be possible to exploit the hard seed dynamics of L. ambigua to establish a permanent perennial ley, where the forage phase regenerates through a hard seed bank in the same manner as in annual ley-farming systems. This is a novel target for domestication of perennial pasture legumes, and if successful, many of the sustainability concerns aired by Crews et al. (2016) will be substantially overcome. 
Acknowledgments We thank Ted Astbury, David Quartermaine and Richard Guinness who facilitated some of the trial work to be done on their farming properties. The contributions and technical expertise of Dr. Neil Ballard, Samantha Lubcke, Robert Harrison and Regina Carr are greatly appreciated. Professor Janet Sprent made comments on an early draft of the manuscript.

Funding Partial funding was provided to the Lebeckia domestication program by ACIAR, the South West Catchment Council and Murdoch University, and this is gratefully acknowledged.

\section{Compliance with ethical standards}

Conflict of interest The authors declare that they have no conflict of interest.

Publisher's note Springer Nature remains neutral with regard to jurisdictional claims in published maps and institutional affiliations.

\section{References}

ABARE (2016) Agriculture, fisheries and forestries in the wheat belt region of Western Australia (2014). ABARE, ww.daff.gov.au/ abares. Accessed June 2016

Angus JF, Peoples MB (2012) Nitrogen from Australian dryland pastures. Crop Pasture Sci 63(9):746-758. https://doi.org/10.1071/CP12161

Anon (2010) Lucerne Australia strategic plan (2010). http:// lucerneaustralia.org.au. Accessed March 2015

Anwar MR, Li Liu D, Farquharson R, Macadam I, Abadi A, Finlayson J, Wang B, Ramilan T (2015) Climate change impacts on phenology and yields of five broadacre crops at four climatologically distinct locations in Australia. Agric Syst 132:133-144

Atwell BJ, Kriedemann PE, Turnbull CG (1999) Plants in action: adaptation in nature, performance in cultivation. Macmillan Education AU, South Yarra

Baskin CC, Baskin JM (2001) Seeds: ecology, biogeography, and evolution of dormancy and germination. Elsevier, New York City

Bathgate A, Pannell DJ (2002) Economics of deep-rooted perennials in Western Australia. Agric Water Manag 53(1-3):117-132. https:// doi.org/10.1016/S0378-3774(01)00160-3

Beard J, Chapman A, Gioia P (2000) Species richness and endemism in the Western Australian flora. J Biogeogr 27(6):1257-1268

Bell LW, Moore GA, Ewing MA, Ryan MH (2006) Production, survival and nutritive value of the perennial legumes Dorycnium hirsutum and D. rectum subjected to different cutting heights. Grass Forage Sci 61(1):60-70. https://doi.org/10.1111/j.1365-2494.2006.00508.x

Bell LW, Robertson MJ, Revell DK, Lilley JM, Moore AD (2008) Approaches for assessing some attributes of feed-base systems in mixed farming enterprises. Anim Prod Sci 48(7):789-798

Bennett RG, Ryan MH, Colmer TD, Real D (2010) Prioritisation of novel pasture species for use in water-limited agriculture: a case study of Cullen in the Western Australian wheatbelt. Genet Resour Crop Evol 58(1):83-100. https://doi.org/10.1007/s10722-010-9567-3

Bouton J, Sumner M (1983) Alfalfa, Medicago sativa L., in highly weathered, acid soils. Plant Soil 74(3):431-436

Brock PM, Graham P, Madden P, Alcock DJ (2013) Greenhouse gas emissions profile for $1 \mathrm{~kg}$ of wool produced in the Yass Region, New South Wales: a life cycle assessment approach. Anim Prod Sci 53(6):495. https://doi.org/10.1071/an12208

Byrne F, Robertson M, Bathgate A, Hoque Z (2010) Factors influencing potential scale of adoption of a perennial pasture in a mixed croplivestock farming system. Agric Syst 103(7):453-462
Caccetta P, Dunne R, George R, McFarlane D (2010) A methodology to estimate the future extent of dryland salinity in the southwest of Western Australia. J Environ Qual 39(1):26-34

Campbell G, Van Wyk B-E (2001) A taxonomic revision of Rafnia (Fabaceae, Crotalarieae). S Afr J Bot 67(2):90-149

Castello M, Croser J, Lulsdorf M, Ramankutty P, Pradhan A, Nelson M, Real D (2013) Breaking primary dormancy in seeds of the perennial pasture legume tedera (Bituminaria bituminosa $\mathrm{CH}$ Stirt. vars albomarginata and crassiuscula). Grass Forage Sci

Chapman R, Asseng S (2001) An analysis of the frequency and timing of false break events in the Mediterranean region of Western Australia. Aust J Agric Res 52(3):367-376

Charnov EL, Schaffer WM (1973) Life-history consequences of natural selection: Cole's result revisited. Am Nat 107(958):791-793. https:// doi.org/10.1086/282877

Clarke C, George R, Bell R, Hatton T (2002) Dryland salinity in southwestern Australia: its origins, remedies, and future research directions. Soil Res 40(1):93-113

Cocks PS (2001) Ecology of herbaceous perennial legumes: a review of characteristics that may provide management options for the control of salinity and waterlogging in dryland cropping systems. Aust J Agric Res 52(2):137-151

Cocks PS, Bennett SJ (1999) Role of pasture and forage legumes in Mediterranean farming systems. Curr Plant Sci Biotechnol Agric 33(1):9-20

Crews TE, Peoples MB (2004) Legume versus fertilizer sources of nitrogen: ecological tradeoffs and human needs. Agric Ecosyst Environ 102(3):279-297. https://doi.org/10.1016/j.agee.2003.09.018

Crews TE, Blesh J, Culman SW, Hayes RC, Jensen ES, Mack MC, Peoples MB, Schipanski ME (2016) Going where no grains have gone before: from early to mid-succession. Agric Ecosyst Environ 223:223-238. https://doi.org/10.1016/j.agee.2016.03.012

Dear BS, Ewing MA (2008) The search for new pasture plants to achieve more sustainable production systems in southern Australia. Aust J Exp Agric 48(4):387-396

Dear BS, Moore GA, Hughes SJ (2003) Adaptation and potential contribution of temperate perennial legumes to the southern Australian wheatbelt: a review. Aust J Exp Agric 43(1):1-18

DeHaan LR, Van Tassel DL (2014) Useful insights from evolutionary biology for developing perennial grain crops. Am J Bot 101(10): 1801-1819. https://doi.org/10.3732/ajb.1400084

Dludlu MN, Chimphango S, Stirton CH, Muasya AM (2017) Differential preference of Burkholderia and Mesorhizobium to $\mathrm{pH}$ and soil types in the Core Cape Subregion, South Africa. Genes 9(1):2

Donald CM (1965) The progress of Australian agriculture and the role of pastures in environmental change. Australasian Medical Publishing Company, Sydney

Dowling RM, McKenzie RA (1993) Poisonous plants: a field guide. Queensland Department of Primary Industries,

Edwards T (2015) Hard seed ecology of Lebeckia ambigua. Murdoch University, Honours

Edwards N, Allen G, McNeill D, Oldham C (1997) Grazing management of tagasaste (Chamaecytisus proliferus) for sheep and cattle production in southern Australia. In: Proceedings of the XVIII International Grassland Congress

Ewing MA, Skinner P, Foster KJ, Nutt BJ, Nichols PGH, Beatty R, Snowball R (2006) Sulla and purple clover as fodder, vol 06/049. RIRDC, Wagga Wagga

Gerding M, O’Hara GW, Bräu L, Nandasena K, Howieson JG (2012) Diverse Mesorhizobium spp. with unique nodA nodulating the South African legume species of the genus Lessertia. Plant Soil 358(1-2):385-401

Gerding M, Howieson JG, O'Hara GW, Real D, Bräu L (2013) Establishment and survival of the South African legume Lessertia spp. and rhizobia in Western Australian agricultural systems. Plant Soil 370(1-2):235-249 
Gerding M, O’Hara GW, Howieson JG, Bräu L (2014) Overcoming nonselective nodulation of Lessertia by soil-borne rhizobium in the presence of inoculant mesorhizobium. Plant Soil 380(1-2):117-132

Goldblatt P (1997) Floristic diversity in the Cape Flora of South Africa. Biodivers Conserv 6(3):359-377. https://doi.org/10.1023/A: 1018360607299

Hacker R, Robertson M, Price R, Bowman A (2009) Evolution of mixed farming systems for the delivery of triple bottom line outcomes: a synthesis of the Grain \& Graze program. Anim Prod Sci 49(10): 966-974

Hackney B, Nutt B, Loi A, Yates R, Quinn J, Piltz J, Jenkins J, Weston L, O'Hare M, Butcher A (2015) "On-demand" hardseeded pasture legumes - a paradigm shift in crop-pasture rotations for southern Australian mixed farming systems. In: Building productive, diverse and sustainable landscapes. Edited by T Acuña, C Moeller, D Parsons and M Harrison. Proceedings of the 17th Australian Agronomy Conference. pp 21-24

Hall D, Jones H, Crabtree W, Daniels T (2010) Claying and deep ripping can increase crop yields and profits on water repellent sands with marginal fertility in southern western Australia. Soil Res 48(2):178 187

Hamblin A (1987) Effect of tillage on soil physical conditions. Tillage: new directions in Australian agriculture/edited by PS Cornish and JE Pratley for the Australian Society of Agronomy

Hamblin A, Hamblin J (1985) Root characteristics of some temperate legume species and varieties on deep, free-draining entisols. Crop Pasture Sci 36(1):63-72

Harris W, Baker M, Williams W (1987) Population dynamics and competition. In: Clover W (eds) CAB International, Wallingford, pp 203-298

Hatton T, Bartle G, Silberstein R, Salama R, Hodgson G, Ward P, Lambert P, Williamson D (2002) Predicting and controlling water logging and groundwater flow in sloping duplex soils in western Australia. Agric Water Manag 53(1):57-81

Henzell T (2007) Australian agriculture: its history and challenges. CSIRO Publishing, Clayton

Herridge DF, Peoples MB, Boddey RM (2008) Global inputs of biological nitrogen fixation in agricultural systems. Plant Soil 311(1-2):118. https://doi.org/10.1007/s11104-008-9668-3

Hobbs RJ, Groves RH, Hopper SD, Lambeck RJ, Lamont BB, Lavorel S, Main AR, Majer JD, Saunders DA (1995) Function of biodiversity in the Mediterranean-type ecosystems of southwestern Australia. In: Davis G, Richardson D (eds) Mediterranean-type ecosystems, Ecological studies, vol 109. Springer, Berlin, pp 233-284. https:// doi.org/10.1007/978-3-642-78881-9 5

Hochman Z, Carberry PS, Robertson MJ, Gaydon DS, Bell LW, McIntosh PC (2013) Prospects for ecological intensification of Australian agriculture. Eur J Agron 44:109-123. https://doi.org/10. 1016/j.eja.2011.11.003

Hope P, Abbs D, Bhend J, Chiew F, Church J, Ekström M, Kirono D, Lenton A, Lucas C, McInnes K (2015) Southern and south-western flatlands cluster report. Climate change in Australia projections for Australia's natural resource management regions: cluster reports: CSIRO and Bureau of Meteorology, Australia

Howieson J (1995) Rhizobial persistence and its role in the development of sustainable agricultural systems in Mediterranean environments. Soil Biol Biochem 27(4):603-610

Howieson J (2015) Then nitrogen crisis - why are some legumes falling out of favour in some farming systems. Proceedings of the nitrogen crisis symposium. Oxford Martins School

Howieson J, Ballard R (2004) Optimising the legume symbiosis in stressful and competitive environments within southern Australia - some contemporary thoughts. Soil Biol Biochem 36(8):1261-1273

Howieson JG, O'Hara GW, Carr SJ (2000) Changing roles for legumes in Mediterranean agriculture: developments from an Australian perspective. Field Crops Res 65(2-3):107-122. https://doi.org/10. 1016/S0378-4290(99)00081-7

Howieson J, Yates R, Foster K, Real D, Besier R (2008) Prospects for the future use of legumes. In: Nitrogen-fixing leguminous symbioses. Springer, Berlin, pp 363-394

Howieson JG, De Meyer SE, Vivas-Marfisi A, Ratnayake S, Ardley JK, Yates RJ (2013) Novel Burkholderia bacteria isolated from Lebeckia ambigua - a perennial suffrutescent legume of the fynbos. Soil Biol Biochem 60:55-64

Ikerd JE (1993) The need for a system approach to sustainable agriculture. Agric Ecosyst Environ 46(1-4):147-160

Kaiser AG, Dear BS, Morris SG (2007) An evaluation of the yield and quality of oat-legume and ryegrass-legume mixtures and legume monocultures harvested at three stages of growth for silage. Aust $\mathrm{J}$ Exp Agric 47(1):25-38

Keating BA, Carberry PS (2010) Emerging opportunities and challenges for Australian broadacre agriculture. Crop Pasture Sci 61(4):269 278. https://doi.org/10.1071/CP09282

Kimura E, Islam MA (2012) Seed scarification methods and their use in forage legumes. Res J Seed Sci 5(2):38-50. https://doi.org/10.3923/ rjss.2012.38.50

Kraaij T, Novellie PA (2010) Habitat selection by large herbivores in relation to fire at the Bontebok National Park (1974-2009): the effects of management changes. Afr J Range Forage Sci 27(1):2127. https://doi.org/10.2989/10220111003703450

Lambers H, Shane MW, Cramer MD, Pearse SJ, Veneklaas EJ (2006) Root structure and functioning for efficient acquisition of phosphorus: matching morphological and physiological traits. Ann Bot 98(4):693-713

Le Maitre D, Midgley J (1992) Plant reproductive ecology. In: Cowling RM (ed) The ecology of fynbos: nutrients, fire and diversity. Cape Town, Oxford University Press, pp 135-174

Le Roux M, Van Wyk B-E (2007) A revision of Lebeckia sect. Lebeckia: the L. sepiaria group. S Afr J Bot 73(1):118-130

Le Roux M, Van Wyk B (2009) A revision of Lebeckia sect. Lebeckia: the L. pauciflora and L. wrightii groups (Fabaceae, Crotalarieae). S Afr J Bot 75(1):83-96

Lefroy E, Hobbs RJ, Scheltema M (1993) Reconciling agriculture and nature conservation: toward a restoration strategy for the Western Australian wheatbelt

Li GD, Lodge GM, Moore GA, Craig AD, Dear BS, Boschma SP, Albertsen TO, Miller SM, Harden S, Hayes RC, Hughes SJ, Snowball R, Smith AB, Cullis BC (2008) Evaluation of perennial pasture legumes and herbs to identify species with high herbage production and persistence in mixed farming zones in southern Australia. Aust J Exp Agric 48(4):449-466

Lindstrom K, Murwira M, Willems A, Altier N (2010) The biodiversity of beneficial microbe-host mutualism: the case of rhizobia. Res Microbiol 161(6):453-463. https://doi.org/10.1016/j.resmic.2010. 05.005

Loi A, Cocks PS, Howieson JG, Carr SJ (1999) Hardseededness and the pattern of softening in Biserrula pelecinus L., Ornithopus compressus L., and Trifolium subterraneum L. seeds. Aust J Agric Res 50(6):1073-1082

Loi A, Howieson JG, Nutt BJ, Carr SJ (2005) A second generation of annual pasture legumes and their potential for inclusion in Mediterranean-type farming systems. Aust J Exp Agric 45(3):289_ 299

Manning J, Goldblatt P (2012) Plants of the Greater Cape Floristic Region. 1: the Core Cape flora. South African National Biodiversity Institute, Pretoria

Miles JW (2001) Achievements and perspectives in the breeding of tropical grasses and legumes. In: Proceedings of the XIX international grassland congress, Sao Paulo, Brazil. pp 509-515

Monjardino M, Revell D, Pannell DJ (2010) The potential contribution of forage shrubs to economic returns and environmental management 
in Australian dryland agricultural systems. Agric Syst 103(4):187197

Moore GA (2001) Soilguide (soil guide): a handbook for understanding and managing agricultural soils. Department of Agriculture and Food, Perth, Western Australia

Moore G, Sanford P, Wiley T (2006) Perennial pastures for Western Australia. Department of Agriculture and Food Western Australia. Bulletin 4690:209-210

Moore AD, Bell LW, Revell DK (2009) Feed gaps in mixed-farming systems: insights from the Grain and Graze program. Anim Prod Sci 49(10):736-748

Moreno JM, Oechel WC (1994) Fire intensity as a determinant factor of postfire plant recovery in southern California chaparral. In: The role of fire in Mediterranean-type ecosystems. Springer, New York, NY, pp 26-45

Moulin L, Munive A, Dreyfus B, Boivin-Masson C (2001) Nodulation of legumes by members of the $\beta$-subclass of Proteobacteria. Nature 411(6840):948-950

Mucina L, Adams JB, Knevel IC, Rutherford MC, Powrie LW, Bolton JJ, van der Merwe JH, Anderson RJ, Bornman TG, le Roux A (2006) Coastal vegetation of South Africa. The vegetation of South Africa, Lesotho and Swaziland. Strelitzia 19:658-583

Muller FL, Raitt LM, Chimphango SBM, Samuels MI, Cupido CF, Boatwright JS, Knight R, Trytsman M (2017) Prioritisation of native legume species for further evaluation as potential forage crops in water-limited agricultural systems in South Africa. Environ Monit Assess 189(10):512. https://doi.org/10.1007/s10661-017-6230-x

Nichols PGH, Loi A, Nutt BJ, Evans PM, Craig AD, Pengelly BC, Dear BS, Lloyd DL, Revell CK, Nair RM, Ewing MA, Howieson JG, Auricht GA, Howie JH, Sandral GA, Carr SJ, de Koning CT, Hackney BF, Crocker GJ, Snowball R, Hughes SJ, Hall EJ, Foster KJ, Skinner PW, Barbetti MJ, You MP (2007) New annual and short-lived perennial pasture legumes for Australian agriculture15 years of revolution. Field Crops Res 104(1-3):10-23. https://doi. org/10.1016/j.fcr.2007.03.016

Norman H, Cocks P, Smith F, Nutt B (1998) Reproductive strategies in Mediterranean annual clovers: germination and hardseededness. Crop Pasture Sci 49(6):973-982

Norman HC, Masters DG, Barrett-Lennard EG (2013) Halophytes as forages in saline landscapes: interactions between plant genotype and environment change their feeding value to ruminants. Environ Exp Bot 92:96-109

Nutt BJ (2012) Incidence and inheritance of hard-seededness and early maturity in Ornithopus sativus. Murdoch University, Murdoch, Western Australia

Ollerton J, Lack A (1996) Partial predispersal seed predation in Lotus corniculatus L. (Fabaceae). Seed Sci Res 6(02):65-69

Ovalle C, Aronson J, Del Pozo A, Avendano J (1990) The espinal: agroforestry systems of the Mediterranean-type climate region of Chile. Agrofor Syst 10(3):213-239

Pang J, Tibbett M, Denton MD, Lambers H, Siddique KHM, Bolland MDA, Revell CK, Ryan MH (2009) Variation in seedling growth of 11 perennial legumes in response to phosphorus supply. Plant Soil 328(1-2):133-143. https://doi.org/10.1007/s11104-009-0088-9

Pausas JG, Keeley JE (2014) Evolutionary ecology of resprouting and seeding in fire-prone ecosystems. New Phytol 204(1):55-65. https:// doi.org/10.1111/nph.12921

Pierce SM, Cowling RM (1991) Disturbance regimes as determinants of seed banks in coastal dune vegetation of the southeastern Cape. J Veg Sci 2(3):403-412. https://doi.org/10.2307/3235933

PSMEIC (1998) Dryland salinity and its impact on rural industries and the landscape. Prime Ministers Science, Engineering and Innovation Council

Puckridge DW, French RJ (1983) The annual legume pasture in cereal-ley farming systems of southern Australia. A review. Agric Ecosyst Environ 9:229-267
Radloff FGT, Mucina L, Snyman D (2014) The impact of native large herbivores and fire on the vegetation dynamics in the Cape renosterveld shrublands of South Africa: insights from a six-yr field experiment. Appl Veg Sci 17(3):456-469. https://doi.org/10.1111/ avsc. 12086

Raeside MC, Nie ZN, Clark SG, Partington DL, Behrendt R, Real D (2012) Evaluation of tedera [(Bituminaria bituminosa (L.) C.H. Stirton var. albomarginata]) as a forage alternative for sheep in temperate southern Australia. Crop Pasture Sci 63(12):1135. https://doi. org/10.1071/cp12293

Raven PH, Evert RF, Eichhorn SE (2005) Biology of plants. WH Freeman, New York

Real D, Formoso F, Martinez A, Risso I, Hugo W, Rostan C, Alzugaray R (2005) Pre-basic seed production of Lotononis bainesii Baker cv.' 'INIA Glencoe'

Real D, Sandral GA, Rebuffo M, Hughes SJ, Kelman WM, Mieres JM, Dods K, Crossa J (2012) Breeding of an early-flowering and drought-tolerant Lotus corniculatus L. variety for the high-rainfall zone of southern Australia. Crop Pasture Sci 63(9):848. https://doi. org/10.1071/cp12173

Reinten E, Coetzee J (2002) Commercialization of South African indigenous crops: aspects of research and cultivation of products. In: Janick J, Whipkey A (eds) Trends in new crops and new uses. ASHS Press, Alexandria, VA

Revell C, Ewing M, Nutt B (2013) Breeding and farming system opportunities for pasture legumes facing increasing climate variability in the south-west of Western Australia. Crop Pasture Sci 63(9):840 847

RIRDC (2014) Pasture seeds program five year plan 2013-2018. RIRDC, Wagga Wagga

Robinson K, Bell LW, Bennett RG, Henry DA, Tibbett M, Ryan MH (2007) Perennial legumes native to Australia - a preliminary investigation of nutritive value and response to cutting. Aust J Exp Agric 47(2):170. https://doi.org/10.1071/ea06043

Ronner E, Franke A, Vanlauwe B, Dianda M, Edeh E, Ukem B, Bala A, Van Heerwaarden J, Giller KE (2016) Understanding variability in soybean yield and response to P-fertilizer and rhizobium inoculants on farmers' fields in northern Nigeria. Field Crop Res 186:133-145

Roper M, Davies S, Blackwell P, Hall D, Bakker D, Jongepier R, Ward P (2015) Management options for water-repellent soils in Australian dryland agriculture. Soil Res 53(7):786-806

Rutherford MC, Powrie LW, Husted LB, Turner RC (2011) Early postfire plant succession in Peninsula Sandstone Fynbos: the first three years after disturbance. S Afr J Bot 77(3):665-674. https://doi.org/ 10.1016/j.sajb.2011.02.002

Ryan M, Bennett R, Denton M, Hughes S, Mitchell M, Carmody B, Edmonds-Tibbett T, Nicol D, Kroiss L, Snowball R Searching for native perennial legumes with pasture potential. In: Proceedings of the 14th Australian agronomy conference, Adelaide, 20082008

Sanchez PA (2002) Soil fertility and hunger in Africa. Science 295(5562): 2019-2020

Sánchez PA, Salinas JG (1981) Low-input technology for managing Oxisols and Ultisols in tropical America. In: Advances in agronomy, vol 34. Elsevier, New York City, pp 279-406

Sanchez PA, Shepherd KD, Soule MJ, Place FM, Buresh RJ, Izac A-MN, Mokwunye AU, Kwesiga FR, Ndiritu CG, Woomer PL (1997) Soil fertility replenishment in Africa: an investment in natural resource capital. In: Buresh RJ, Sanchez PA, Calhoun F (eds) Replenishing soil fertility in Africa, SSSA special publication, vol 51. Madison, WI, Soil Science Society of America and American Society of Agronomy, pp 1-46. https://doi.org/ 10.2136/sssaspecpub51.c1

Savio HL (2011) Sustainable Agriculture in Ancient Rome. Senior Capstone Projects. 2. https://digitalwindow.vassar.edu/senior capstone/2 
Schoknecht N (2015) Report card on sustainable natural-resource use in the agricultural regions of Western Australia. Soil Res 53(6):695709. https://doi.org/10.1071/SR14267

Schutte A, Vlok J, Van Wyk B-E (1995) Fire-survival strategy-a character of taxonomic, ecological and evolutionary importance in fynbos legumes. Plant Syst Evol 195(3-4):243-259

Scott BJ, Ewing MA, Williams R, Humphries AW, Coombes NE (2008) Tolerance of aluminium toxicity in annual species and lucerne. Aust J Exp Agric 48(4):499-511. https://doi.org/10.1071/EA07137

Short J, Atkins L, Turner B (2005) Diagnosis of mammal declines in Western Australia, with particular emphasis on the possible role of feral cats and poison peas. Perth, CSIRO Sustainable Ecosystems

Silsbury J, Brittan N (1955) Distribution and ecology of the genus Kennedya Vent. in Western Australia. Aust J Bot 3(1):113-135

Small E (2011) Alfalfa and relatives. Evolution and classification of Medicago. NRC Research Press, Ottawa

Smith ST (1962) Some aspects of soil salinity in Western Australia. University of Western Australia

Smith FP, Norman HC, Cocks PS, Nutt BJ (1998) Reproductive strategies in Mediterranean annual clovers: germination and hardseededness. Aust J Agric Res 49(6):973-982

Sprent JI, Ardley J, James EK (2017) Biogeography of nodulated legumes and their nitrogen-fixing symbionts. New Phytol 215(1): $40-56$

Stephens D, Lyons T (1998) Rainfall-yield relationships across the Australian wheatbelt. Aust J Agric Res 49(2):211-224

Sudmeyer R, Simons J (2008) Eucalyptus globulus agroforestry on deep sands on the southeast coast of Western Australia: the promise and the reality. Agric Ecosyst Environ 127(1-2):73-84

Sudmeyer RA, Edward A, Fazakerley V, Simpkin L, Foster I (2016) Climate change: impacts and adaptation for agriculture in Western Australia

Suriyagoda LDB, Suriyagoda LDB, Real D, Renton M, Lambers H (2013) Establishment, survival, and herbage production of novel, summer-active perennial pasture legumes in the low-rainfall cropping zone of Western Australia as affected by plant density and cutting frequency. Crop Pasture Sci 64(1):71-85. https://doi. org/10.1071/CP12398

Taylor AG (1988) SMP: solid matrix priming of seeds. Sci Hortic 37(12):1-11. https://doi.org/10.1016/0304-4238(88)90146-X
Taylor GB (2005) Hardseededness in Mediterranean annual pasture legumes in Australia: a review. Aust J Agric Res 56(7):645-661

Taylor GB, Revell CK (2002) Seed softening, imbibition time, and seedling establishment in yellow serradella. Aust J Agric Res 53(9): 1011-1018. https://doi.org/10.1071/AR01201

Turner NC, Asseng S (2005) Productivity, sustainability, and rainfall-use efficiency in Australian rainfed Mediterranean agricultural systems. Aust J Agric Res 56(11):1123. https://doi.org/10.1071/ar05076

Turner NC, Ward PR (2002) The role of agroforestry and perennial pasture in mitigating water logging and secondary salinity: summary. Agric Water Manag 53(1):271-275

Van Wyk B-E (1989) The taxonomic significance of cyanogenesis in Lotononis and related genera. Biochem Syst Ecol 17(4):297-303

Van Wyk B-E (2003) The value of chemosystematics in clarifying relationships in the genistoid tribes of papilionoid legumes. Biochem Syst Ecol 31(8):875-884

Ward PR (2006) Predicting the impact of perennial phases on average leakage from farming systems in south-western Australia. Aust J Agric Res 57(3):269-280

Watterson I, Whetton P, Moise A, Timbal B, Power S, Arblaster J, McInnes KL (2007) Regional climate change projections. In: Climate Change in Australia: Technical Report 2007. CSIRO, Australian Bureau of Meteorology, Clayton, Vic, pp. 49-107. Available at: www.climatechangeinaustralia.gov.au/technical report.php

Wiley T, Oldham CM, Allen GM, Wiese T (1994) Tagasaste. Bulletin 4291. 23 p. Department of Agriculture Western Australia, Australia

Wisheu IC, Rosenzweig ML, Olsvig-Whittaker L, Shmida A (2000) What makes nutrient-poor Mediterranean heathlands so rich in plant diversity? Evol Ecol Res 2(7):935-955

Yang Z, Culvenor R, Haling R, Stefanski A, Ryan M, Sandral G, Kidd D, Lambers H, Simpson R (2015) Variation in root traits associated with nutrient foraging among temperate pasture legumes and grasses. Grass Forage Sci

Yates R, Foster K, Nichols P, Ewing M (2006) Flamenco - a new variety of sulla for southern Australia. In: Online Proc. Australian Society of Agronomy Conference. http://www.regional.org.au/au/asa/2006/ poster/systems/4842 yatesr.htm. Accessed August 2016 